\title{
Program live update pemberitaan risiko Covid-19 di televisi nasional Indonesia
}

\author{
Evi Rosfiantika ${ }^{1}$, Rangga Saptya Mohamad Permana ${ }^{2}$, Jimi Narotama Mahameruaji ${ }^{3}$ \\ 1,2,3 Universitas Padjadjaran, Bandung, Indonesia
}

\begin{abstract}
ABSTRAK
Penyebaran virus SARSCOV2 terjadi di seluruh dunia dalam waktu yang sangat cepat. Banyak warga dunia merasa khawatir dan panik terinfeksi virus salah satunya diakibatkan pemberitaan yang salah. Warga membutuhkan informasi yang akurat dan terpercaya terutama yang dikeluarkan oleh pemerintah. Setiap negara melakukan pengendalian informasi, termasuk Indonesia. Pemerintah Indonesia membentuk Gugus Tugas Percepatan Penanganan Covid-19 dengan dikeluarkannya Keputusan Presiden Nomor 7 tahun 2020 tentang Gugus Tugas Percepatan Penanganan Covid-19. Gugus Tugas ini juga secara rutin menyajikan informasi dengan cara melakukan live update di stasiun televisi nasional setiap harinya. Tujuan penelitian dalam artikel ini adalah untuk mengetahui isi berita risiko penyebaran virus SARSCOV2 dalam upaya mengurangi risiko pandemi Covid-19 pada live update Gugus Tugas Percepatan Penanganan Covid-19 di televisi nasional dalam konteks komunikasi risiko. Penulis memakai metode studi kasus dengan teknik analisis teks guna menganalisis data-data yang telah dihimpun melalui observasi siaran televisi. Hasil penelitian menunjukkan bahwa isi berita terkait update Covid-19 adalah yang paling banyak disampaikan (11 kali). Mayoritas makna isi berita yang dari siaran program live update televisi tersebut bersifat "menginformasikan" dan "mengingatkan", yang berarti dalam tahap-tahap komunikasi risiko O'Neill, informasi dan pesan-pesan yang diberikan dalam siaran program televisi live update Gugus Tugas Percepatan Penanganan Covid-19 ini sudah melewati tahapan sebelum bencana dan tahapan peringatan, serta berada dalam bilik non-partisipasi, manipulasi/terapi, dan informasi dalam konsep "Tangga Arnstein".
\end{abstract}

Kata-kata Kunci: Pemberitaan; komunikasi risiko; Covid-19; program live update; televisi nasional Indonesia

\section{Live update program on Covid-19 risk reporting on Indonesian national television}

\begin{abstract}
SARSCOV2 has spread rapidly throughout the world. Many citizens of the world feel worried and panic about being infected, one of which is caused by false reporting. Citizens need accurate and reliable information, especially those issued by the government. Each country controls information, including Indonesia. The Indonesian government formed the Task Force for the Acceleration of COVID-19 Handling with the issuance of Presidential Decree No. 7 of 2020 concerning the Task Force for the Acceleration of Handling of the COVID-19, and also routinely presents information by conducting live updates on national television stations every day. The purpose of this research is to find out the news content of the risk of spread of the SARSCOV2 virus in an effort to reduce the risk of a COVID-19 pandemic in the Task Force's live update program on national television in the context of risk communication. The author uses the case study method with text analysis techniques to analyze the data that has been collected through television broadcast observation. The results showed that news content related to the COVID-19 update was the most widely reported (11 times). The majority of the meaning of the news content is "inform" and "remind", which means in the stages of O'Neill risk communication, information and messages provided has passed the before the disaster stage and the warning stage, and is in the room of non-participation, manipulation/therapy, and information in the concept of "Arnstein's Ladder".
\end{abstract}

Keywords: Reporting; risk communication; Covid-19; live update program; Indonesian national television

Korespondensi: Evi Rosfiantika, S.Pd., M.Si. Fakultas Ilmu Komunikasi, Universitas Padjadjaran. Jalan Raya Bandung-Sumedang KM. 21 Jatinangor 45363.Email: evi.rosfiantika@unpad.ac.id 


\section{PENDAHULUAN}

Penyebaran virus SARSCOV2 terjadi di seluruh dunia dalam waktu yang sangat cepat. Banyak warga dunia merasa khawatir dan panik terinfeksi virus salah satunya diakibatkan pemberitaan yang salah. Warga membutuhkan informasi yang akurat dan terpercaya terutama yang dikeluarkan oleh pemerintah. Setiap negara melakukan pengendalian informasi yang berkembang untuk menginformasikan risiko dalam mencegah penularaan virus tersebut dengan cara yang berbeda sesuai dengan kebijakan masing-masing.

Di Indonesia, informasi tentang penyebaran virus Covid-19 direspon secara berbeda. WHO telah memperingatkan Indonesia sejak awal 2020. Para ahli juga memperingatkan hal yang sama. Kecemasan tentang timbulnya virus yang buruk menjadi percakapan sehari-hari masyarakat, baik dalam obrolan langsung dan di media sosial (Sulistyaningtyas et al., 2020).

Indonesia awalnya membentuk Tim Tanggap Covid-19 DKI Jakarta, kemudian setelah pemerintah membentuk Gugus Tugas Percepatan Penanganan Covid-19 dengan dikeluarkannya Keputusan Presiden Nomor 7 tahun 2020 tentang Gugus Tugas Percepatan Penanganan COVID -19. Gugus Tugas percepatan Penanganan Covid-19 berada di bawah dan bertanggung jawab kepada presiden. Gugus Tugas ini bertujuan untuk: (1) Meningkatkan ketahanan nasional di bidang Kesehatan; (2) Mempercepat penanganan Covid-19 melalui sinergi antar kementerian/ lembaga dan pemerintah daerah;

Meningkatkan antisipasi perkembangan eskalasi penyebaran Covid-19; (4) Meningkatkan sinergi pengambilan kebijakan operasional; dan (5) Meningkatkan kesiapan dan kemampuan dalam mencegah, mendeteksi, dan merespons terhadap Covid-19.

Pemerintah dan pihak-pihak yang berwenang bertanggung jawab untuk menginformasikan risiko berdasarkan data dan informasi yang akurat sehingga dapat menumbuhkan kepercayaan masyarakat. Dengan informasi yang terpercaya mereka lebih siap dalam menghadapi wabah dan bisa meminimalkan risiko yang terjadi. Salah satu media massa yang diandalkan pemerintah untuk meyebarluaskan informasi-informasi ini adalah televisi, karena selain memiliki karakteristik audio-visual, televisi juga merupakan salah satu sarana hiburan paling "murah" bagi mayoritas masyarakat Indonesia yang masih memiliki tingkat budaya baca yang rendah (Abdullah et al., 2017).

Dalam memenuhi kebutuhan informasi masyarakat gugus tugas ini menyiarkan pemberitaan risiko penyebaran virus di media televisi nasional dan banyak disebarkan lagi 
lewat kanal media lain. Informasi tersebut disesuaikan dengan platform dari setiap media, karena tiap media memiliki kebijakan dan redaksi yang berbeda satu sama lain (Abdullah \& Permana, 2020). Televisi nasional siaran bebas (free to air) masih menjadi "primadona" bagi masyarakat Indonesia berkat keunggulan konten informasi, hiburan, dan opini yang disiarkan kepada khalayak secara gratis (C. Nugroho, 2018). Oleh karena itu, televisi masih menjadi media yang paling digemari sebagai media hiburan dan informasi (Abdullah \& Puspitasari, 2018). Menurut sebuah riset, setiap minggunya, rata-rata masyarakat Indonesia menghabiskan waktu 30 jam untuk menonton televisi, yang berarti 4-5 jam per hari (Gemiharto et al., 2017).

Gugus tugas memberikan pemberitaan risiko virus SARSCOV2 kepada masyarakat tentang informasi yang mereka butuhkan. Informasi reguler yang disediakan melalui media massa dapat menjadi semacam early warning system bagi masyarakat (Asteria, 2016). Komunikasi risiko yang efektif harus fokus pada masalah yang paling perlu dipahami oleh penerima. Jika suatu komunikasi menghilangkan informasi penting, maka itu menjadi tanggung jawab komunikator.

Komunikasi risiko bertujuan untuk memberi orang informasi yang mereka butuhkan untuk membuat keputusan tentang risiko. Karena kendala waktu dan perhatian yang sangat terbatas, maka komunikasi yang sukses dapat membantu orang untuk mengidentifikasi risiko yang cukup besar. Komunikasi yang sukses dan efektif dapat terwujud jika komunikator dapat memanfaatkan media massa secara efektif, karena media komunikasi memegang peranan yang vital dalam upaya kesiapsiagaan dan peringatan dini kepada masyarakat dalam konteks sistem informasi bencana (Lestari et al., 2018). Covid-19 sendiri merupakan bencana yang tergolong ke dalam biological disasters (terdiri dari epidemics and insect infestations) (Sjuchro et al., 2019).

Komunikasi risiko bisa didefinisikan sebagai proses interaktif pertukaran informasi dan opini antara stakeholder mengenai sifat dan risiko terkait bahaya pada individu atau masyarakat dan respons yang sesuai untuk meminimalkan risiko. Kunci perubahan perilaku terletak pada desain komunikasi risiko untuk mengubah persepsi orang-orang mengenai risiko dan untuk meningkatkan kesediaan mereka untuk mengelola risiko. Risiko bencana dapat dikurangi melalui komunikasi bencana yang juga memerlukan perhatian dari semua kelompok seperti pemerintah, media, dan lainnya (Lestari et al., 2019).

Beberapa model terbaru dari perilaku perlindungan diri mendalilkan bahwa pesanpesan berbeda penting di setiap tahap dalam 
proses. Informasi mengenai besarnya risiko bisa menjadi hal paling penting dalam membuat orang-orang sadar mengenai risiko yang belum pernah mereka dengar, ketika informasi mengenai kerentanan pribadi lebih penting dalam transisi kesadaran hingga mencapai keputusan untuk bertindak.

Tindakan komunikasi risiko spesifik bisa dilihat dalam lingkungan yang berlainan, dengan setiap lingkungan dan khalayak menentukan tujuan, pendekatan, dan pesan keamanan. Untuk tujuan keamanan masyarakat, empat tahap berbeda yang telah diidentifikasi tertuang dalam tabel (1).

Setiap tahap memerlukan berbagai tipe pesan yang berbeda, karena perubahan persepsi dari risiko. Pemahaman akan penilaian terhadap risiko bencana yang dipersepsi masyarakat menjadi kunci dalam rangka mendesain komunikasi risiko yang efektif (Rachmawati et al., 2014). Salah satu kunci untuk pendekatan ini adalah menggunakan waktu peringatan. Selama periode peringatan, persepsi orangorang mengenai risiko menjadi lebih realistis, biaya tindakan akan menurun dan keuntungan meningkat. Jika Socioeconomic Status (SES) sudah ditetapkan sebagai otoritas untuk respons banjir dan badai, pesan keselamatan lebih mungkin dilakukan.

Berbagai media komunikasi digunakan untuk menyampaikan risiko. Media-media yang digunakan dalam model tradisional antara lain label produk, selebaran, tanda, manual, dan iklan. Namun, pendekatan lain seperti komunikasi tatap muka digunakan, misalnya, untuk memberi tahu pasien tentang risiko

Tabel 1 Empat Tahap Komunikasi Risiko

\begin{tabular}{|c|c|c|c|}
\hline Sebelum Bencana & Tahap Peringatan & $\begin{array}{c}\text { Selama dan Sesudah } \\
\text { Bencana }\end{array}$ & Pemulihan \\
\hline $\begin{array}{l}\text { - } \text { Membangun } \\
\text { ketahanan } \\
\text { - Membangun otoritas } \\
\text { agensi darurat } \\
\text { - Meningkatkan } \\
\text { kesadaran bahaya } \\
\text { dan risiko } \\
\text { - Mendorong perilaku } \\
\text { keselamatan yang } \\
\text { sesuai } \\
\text { - Menginformasikan } \\
\text { masyarakat mengenai } \\
\text { peringatan }\end{array}$ & 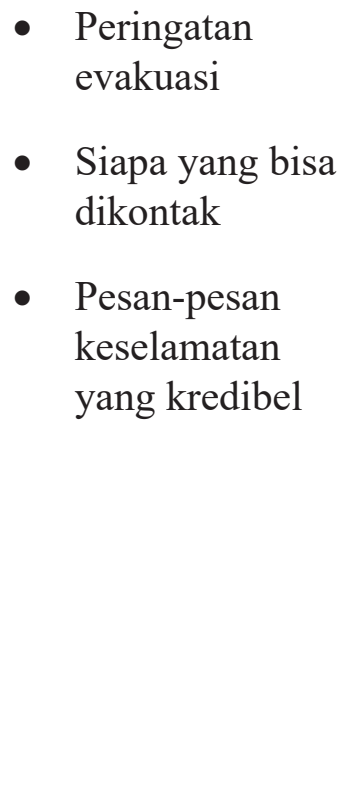 & 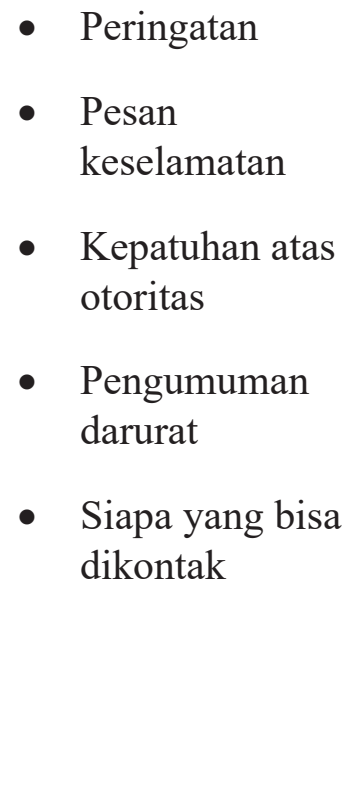 & 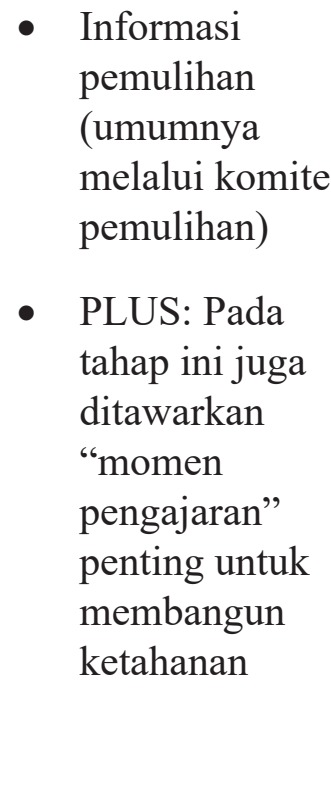 \\
\hline
\end{tabular}

Sumber: (O’Neill, 2004) 
medis. Juga, media massa, melalui siaran berita dan program magazine di televisi juga menjadi sumber yang semakin penting dari informasi risiko, serta bersifat praktis dan lebih menarik. Oleh karena itu, media massa yang bersifat elektronik cenderung lebih diminati oleh khalayak daripada media massa berbasis cetak (Kurniawati, 2019). Akhirnya, teknologi telah menyediakan saluran tambahan, seperti kaset video, yang lebih sering menyertai produk baru, dan nomor telepon bebas pulsa dan internet untuk mengomunikasikan informasi spesifik kepada pihak yang berkepentingan.

Saluran baru untuk mengomunikasikan informasi risiko sedang dikembangkan di beberapa tahun terakhir diadaptasi untuk mengubah teknologi. Saluran yang paling cepat berkembang adalah sistem informasi yang diakses komputer (seperti CD-ROM dan internet). Kehadiran internet juga mengubah budaya menonton televisi khalayak, dimana dengan kehadiran internet, platform untuk menonton televisi lebih beragam, misalnya saja dengan menggunakan smartphone, di mana dengan platform tersebut, kegiatan menonton televisi bisa dilakukan tanpa batasan ruang dan waktu, dan pemirsa dapat memiliki kuasa lebih untuk menentukan saluran dan program televisi yang mereka kehendaki (Permana et al., 2019).

Medium-medium baru ini berbagi elemen dengan saluran tatap muka dan media massa tradisional. Mereka dialamatkan secara individual, dan informasi dapat disesuaikan untuk memenuhi kebutuhan individu; namun, pesan serupa mungkin dikomunikasikan secara bersamaan ke sejumlah besar konsumen. Dalam konteks konsumsi media terkait pencarian informasi Covid-19 oleh khalayak di Indonesia selama masa pandemi menunjukkan bahwa televisi swasta, website dan media sosial dari asosiasi kesehatan serta komentar individu adalah tiga media yang paling banyak digunakan (Rochyadi-Reetz et al., 2020).

Tantangan dalam komunikasi risiko adalah bagaimana menargetkan pesan keselamatan yang tepat ke khalayak yang tepat. Terdapat pertanyaan yang berhubungan dengan efektivitas pembiayaan-akan terasa sia-sia jika target audiensnya kurang merespons pada pesan yang disampaikan. Jika setiap proyek keselamatan masyarakat fokus pada khalayakyang berbeda, dengan metode yang berbeda dan pesan yang digunakan untuk mencapai tujuan mereka, sistem perlu dikembangkan untuk secara logis mengkategorikan tipe komunikasi dan tipe pendekatan keterlibatan publik yang berbeda. Menurut (Prasanti \& Fuady, 2017), pendekatan interaktif bisa lebih efektif di negara dunia ketiga seperti Indonesia, karena pendekatan ini lebih menawarkan nilai-nilai humanis dan kultural kepada khalayak.

"Tangga Arnstein" telah digunakan 
secara luas saat ini dan telah mengarah ke topik ini. "Tangga" Arnstein melibatkan tingkat pemberdayaan publik yang lebih kuat dan menyajikan transparansi dalam proses komunikasi. Konsep ini telah diterapkan pada sektor komunikasi risiko, dan terlihat dalam tabel (2).

Salah satu komponen yang menjadi faktor penting dalam efektivitas komunikasi risiko adalah kredibilitas komunikator. Dalam konteks program live update Covid-19 di Indonesia, komunikator yang dalam hal ini diwakili oleh juru bicara (jubir) pemerintah, harus bisa memerankan fungsi public relations (PR) yang baik, agar informasi yang diberikan bisa dicerna dan diolah dengan baik oleh khalayak, termasuk di dalamnya para jurnalis, yang bertanggung jawab mengolah pesan-pesan tersebut menjadi sebuah berita yang nantinya akan disajikan kepada khalayak. Dalam mengembangkan siaran pers, PR harus jeli mengolah dan meyampaikan pesan-pesan dari perspektif

Tabel 2 "Tangga Arnstein" (Arnstein's Ladder of Citizen Participation)

\begin{tabular}{|c|c|c|}
\hline Tahap & Contoh & Pendekatan Komunikasi Risiko \\
\hline Pemberdayaan & $\begin{array}{l}\text { Pengembangan } \\
\text { masyarakat: sumber } \\
\text { daya dan fasilitas } \\
\text { masyarakat lokal } \\
\text { untuk ketahanan } \\
\text { mandiri }\end{array}$ & $\begin{array}{l}\text { Sumber daya organisasi masyarakat selama tahap } \\
\text { pemulihan (contohnya Unit Kebakaran Masyarakat } \\
\text { dan Keamanan Kebakaran Masyarakat) }\end{array}$ \\
\hline Kolaborasi & $\begin{array}{l}\text { Edukasi masyarakat: } \\
\text { penyelesaian } \\
\text { masalah di level } \\
\text { masyarakat (dua } \\
\text { arah) (contoh: } \\
\text { partisipasi dalam } \\
\text { perencanaan) }\end{array}$ & $\begin{array}{l}\text { - Komite penasihat rekonstruksi } \\
\text { - Komite perencanaan kolaborasi bencana (contoh } \\
\text { kelompok koordinasi komunikasi publik) }\end{array}$ \\
\hline Konsultasi & $\begin{array}{l}\text { Edukasi masyarakat: } \\
\text { penyelesaian } \\
\text { masalah dalam } \\
\text { level individu atau } \\
\text { kelompok kecil } \\
\text { (dua arah) (contoh: } \\
\text { pembelajaran tatap } \\
\text { muka) }\end{array}$ & $\begin{array}{l}\text { Workshop, demonstrasi, pertemuan publik skala } \\
\text { kecil, pelatihan }\end{array}$ \\
\hline Informasi & $\begin{array}{l}\text { Kesadaran publik } \\
\text { (satu arah) }\end{array}$ & $\begin{array}{l}\text { Info baris, surat kabar, leaflet, informasi melalui } \\
\text { media massa, pertemuan publik, pelatihan }\end{array}$ \\
\hline Manipulasi/terapi & $\begin{array}{l}\text { Marketing sosial } \\
\text { (persuasi satu arah) }\end{array}$ & Kampanye periklanan \\
\hline Non-partisipasi & $\begin{array}{l}\text { Pengumuman } \\
\text { darurat (mandat satu } \\
\text { arah) }\end{array}$ & $\begin{array}{l}\text { Peringatan, apa yang harus dan tidak boleh } \\
\text { dilakukan, pengumuman evakuasi }\end{array}$ \\
\hline
\end{tabular}

Sumber: (O’Neill, 2004) 
jurnalis, sehingga dapat memahami kebutuhankebutuhan para jurnalis (Nuraini, 2016).

Menurut (Wogalter et al., 2005), terdapat beberapa karakteristik sumber komunikasi yang efektif. Lima elemen model komunikasi mewakili karakteristik yang ditemukan untuk memengaruhi efektivitasnya. Dengan mempertimbangkan karakteristik masingmasing elemen dalam model komunikasi sebagai variabel independen dan penerima tanggapan pada tahap berurutan dari model pemrosesan informasi sebagai variabel dependen, interaksi antara model komponen menjadi jelas. Hal tersebut dideskripsikan dalam tabel (3) .

Komunikator yang kredibel dapat menghasilkan lebih banyak perubahan sikap positif, mendapatkan lebih banyak perubahan perilaku, meningkatkan "rasa takut" dan kewaspadaan khalayak, serta menghambat argumen kontra ke pesan karena orang-orang cenderung untuk menurunkan pertahanan mereka dan tidak berpikir sebanyak tanggapan kognitif. Selain itu, dari segi kognitif, daya tarik fisik komunikator juga memengaruhi efektivitas pesan. Komunikator yang secara fisik menarik dan disukai umumnya lebih sukses daripada yang tidak menarik.

Berdasarkan paparan yang telah diuraikan, maka fokus dari penelitian ini adalah bagaimana isi berita risiko penyebaran virus SARSCOV2 pada live update Gugus Tugas Percepatan Penanganan Covid-19 di televisi nasional dalam konteks komunikasi risiko dengan tujuan penulisan untuk mengetahui isi berita risiko penyebaran virus SARSCOV2 dalam upaya mengurangi risiko pandemi Covid-19 pada live update Gugus Tugas Percepatan Penanganan Covid-19 di televisi nasional dalam konteks komunikasi risiko.

Tabel 3 Matriks Komunikasi Persuasi McGuire (1980)

\begin{tabular}{llll}
\hline $\begin{array}{l}\text { Output: Dependent variables } \\
\text { (response steps mediating }\end{array}$ & Input: Independent variables & Source Message Channel Receiver Destination \\
\cline { 2 - 3 } persuasion) & & \\
\hline Exposure to communication & & \\
Attended to it \\
Reacted effectively to it \\
Comprehended it \\
Yielded to its arguments \\
Stored and retained it \\
Searched and retrieved it \\
Decided to use it or not \\
Behaved according to it \\
Postbehavioral consolidating
\end{tabular}




\section{METODE PENELITIAN}

Kasus penanganan Covid-19 dalam konteks penyebaran komunikasi risiko di tiap negara memiliki ciri khas masing-masing, tergantung dari pengelolaan media, pengelolaan pesan, komunikator, dan khalayaknya. Oleh karena itu, isi berita risiko penyebaran virus SARSCOV2 dalam upaya mengurangi risiko pandemi Covid-19 pada live update gugus percepatan penanganan Covid-19 di televisi Indonesia pun terbilang unik dan berbeda dari negara lain.

Kita mendefinisikan kasus sebagai sebuah kelas peristiwa instan. Istilah "kelas peristiwa" merujuk pada suatu fenomena kepentingan saintis, seperti revolusi, tipe rezim pemerintahan, jenis sistem ekonomi, atau tipe kepribadian yang dipilih oleh peneliti untuk penelitian dengan tujuan untuk mengembangkan teori berdasarkan sebab-sebab kemiripan atau perbedaan diantara kasus-kasus dalam kelaskelas peristiwa (George \& Bennett, 2005).

Metode penelitian yang digunakan dalam penelitian ini adalah metode penelitian kualitatif. Pemilihan metode ini berangkat dari pemberitaan Covid-19 di televisi yang menunjukkan narasi-narasi mengenai bahaya pandemi ini. Oleh sebab itu perlu ada upaya untuk mengurangi dampak dari bencana tersebut lewat pemberitaan di televisi, sehingga penulis bermaksud mengkaji pemberitaan risiko bencana yang dilakukakan oleh gugus percepatan penanganan Covid-19 di televisi. Oleh sebab itu, penulis memilih analisis isi untuk menjaring makna dalam setiap pemberitaan mengenai risiko penyebaran virus SARSCOV2 di Indonesia. Teknik analisis isi digunakan untuk menganalisis data-data yang dihimpun dalam penelitian ini. Awal mula dari teknik analisis ini adalah harus ada fenomena komunikasi yang dapat diamati, dalam arti bahwa peneliti harus lebih dulu dapat merumuskan dengan tepat apa yang ingin diteliti dan semua tindakan harus didasarkan pada tujuan tersebut (Bungin, 2011)

Analisis isi kualitatif disebut pula sebagai Ethnographic Content Analysis (ECA), yaitu perpaduan analisis isi objektif dengan observasi partisipan. Artinya, dalam ECA, peneliti berinteraksi dengan material-material dokumentasi. Beberapa hal yang harus diperhatikan oleh peneliti yakni: (1) Isi (content) atau situasi sosial seputar dokumen (pesan/ teks) yang diteliti. Misalnya, peneliti harus mempertimbangkan faktor ideologi institusi media (karena institusi media memiliki latar belakang yang bisa saja berbeda dan mengemas suatu informasi menurut ideologinya (Desilvani et al., 2017)) dan latar belakang pembaca, karena faktor-faktor ini menentukan isi berita dari media tersebut; (2) Proses atau bagaimana suatu produk media/isi pesannya dikreasi secara aktual dan diorganisasikan secara bersama. 
Dalam konteks televisi, proses kreasi ini berjalan sesuai dengan kebijakan programming masing-masing institusi televisi yang bisa saja berbeda satu sama lain, tergantung dari orientasi khalayak program tersebut (Fahruddin \& Asy'ari, 2019). Misalnya, bagaimana berita diproses, bagaimana format rubrik pada netizen yang dianalisis tadi disesuaikan dengan keberadaan dari tim pemberitaan, bagaimana realitas objektif diedit ke dalam realitas media massa, dan lain sebagainya; dan (3) Emergence, yakni pembentukan secara gradual atau bertahap dari makna sebuah pesan melalui pemahaman dan interpretasi. Di sini peneliti menggunakan dokumen atau teks untuk membantu memahami proses makna dari aktivitas-aktivitas sosial. Dalam proses ini, peneliti akan mengetahui apa dan bagaimana si pembuat pesan dipengaruhi oleh lingkungan sosialnya atau bagaimana si pembuat pesan mendefinisikan sebuah situasi (Ida, 2014).

Fenomena komunikasi yang dipilih pada penelitian ini adalah mengenai isi berita risiko penyebaran virus SARSCOV2 pada live update gugus percepatan penanganan Covid-19 di televisi. Objek penelitian pada penelitian ini adalah program live update virus korona oleh Gugus Tugas Covid-19 di televisi nasional Indonesia, sedangkan subjek penelitianya merupakan pihak-pihak yang menjadi narasumber dalam program live update.

Penulis memulai analisis dengan menggunakan kategori-kategori tertentu, mengklasifikasikan data tersebut dengan kriteria-kriteria tertentu serta melakukan prediksi dengan teknik analisis yang tertentu pula. Unit analisis yang dikaji dalam penelitian ini adalah 15 tayangan live update Gugus Tugas Percepatan Penanganan Covid-19 di televisi terkait dengan risiko penyebaran virus SARSCOV2, seperti yang tertuang dalam tabel (4).

Terdapat tiga komunikator yang menyampaikan pesan-pesan yang berkonteks

Tabel 4 Unit Analisis

\begin{tabular}{ccc}
\hline Bulan & Tanggal & $\begin{array}{c}\text { Jumlah } \\
\text { Tayangan }\end{array}$ \\
\hline Maret & 8 & 1 \\
April & 2,28 & 2 \\
Mei & 29 & 1 \\
Juni & $10,14,16,17,18,19,19($ pukul 12.00), 20,21, 25, 26 & 11 \\
\hline Total & & $\mathbf{1 5}$ \\
\hline
\end{tabular}

Sumber: Olahan Penulis, 2020 
komunikasi risiko dalam program televisi live update Covid-19 ini, yaitu Kol. CKM (Purn.) dr. Achmad Yurianto (Juru Bicara Pemerintah pada Gugus Tugas Percepatan Penanganan Covid-19), dr. Reisa Broto Asmoro (Anggota Tim Komunikasi Publik Gugus Tugas Percepatan Penanganan Covid-19) dan Lula Kamal (Promotor Kesehatan Masyarakat). Ketiga komunikator publik ini menyampaikan pesan-pesan terkait perkembangan harian Covid-19 di Indonesia (baik itu jumlah kasus per provinsi atau dalam jumlah keseluruhan), cara menghindarinya (jauhi kerumunan, rajin mencuci tangan dan jangan lupa memakai masker), hingga informasi-informasi klinis terkait Covid-19. Setelah itu, isi pesan berita yang dikemukakan oleh para komunikator/ narasumber kemudian dimaknai dan dibuat kategorisasi.

\section{HASIL DAN PEMBAHASAN}

Penulis memilih 15 tayangan program live TV Gugus Tugas Penanganan Covid-19 dalam rentang Bulan Maret - Juni 2020. Hasilnya

Tabel 5 Hasil Penelitian

\begin{tabular}{|c|c|c|c|}
\hline Tanggal & Narasumber & Isi Berita & Makna Isi Berita \\
\hline $\begin{array}{l}8 \text { Maret } \\
2020\end{array}$ & $\begin{array}{l}\text { Achmad } \\
\text { Yurianto }\end{array}$ & $\begin{array}{l}\text { Warga Negara Indonesia terjangkit virus corona } \\
\text { jenis baru di Indonesia bertambah } 2 \text { orang, } \\
\text { sehingga ada total } 6 \text { kasus positif korona di } \\
\text { Indonesia, penambahan } 2 \text { pasien ini berdasarkan } \\
\text { penelurusan dari } 2 \text { pasien positif korona pertama, } \\
\text { yakni kasus } 05 \text { (laki-laki } 55 \text { tahun) sedangkan } 1 \\
\text { orang lainnya yaitu kasus } 06 \text { dinyatakan positif } \\
\text { berdasarkan hasil laboratorium; yaitu WNI anak } \\
\text { buah kapal Diamond Princess yang kini sedang } \\
\text { menjalani masa observasi di Pulau Sebaru Kecil, } \\
\text { Kepulauan Seribu. } 2 \text { orang pasien positif korona } \\
\text { tambahan ini dalam kondisi stabil bahkan tidak } \\
\text { menunjukkan gejala demam tinggi pilek maupun } \\
\text { batuk. }\end{array}$ & $\begin{array}{l}\text { Sumber asal dari } \\
\text { penderita kasus } \\
\text { awal Covid-19. }\end{array}$ \\
\hline \multirow[t]{3}{*}{$\begin{array}{l}2 \text { April } \\
2020\end{array}$} & \multirow[t]{3}{*}{$\begin{array}{l}\text { Achmad } \\
\text { Yurianto }\end{array}$} & $\begin{array}{l}\text { "Kami sangat bangga dan kagum dengan } \\
\text { inisiatif masyarakat Indonesia untuk memastikan } \\
\text { orang lain untuk tetap tinggal di rumah, } \\
\text { menyelenggarakan konser virtual, video inspiratif } \\
\text { dan menghibur, terima kasih terhadap upaya } \\
\text { masyarakat yang tidak hanya patuh dan disiplin } \\
\text { untuk dirinya saja tapi juga menyemangati untuk } \\
\text { melakukannya bersama-sama." }\end{array}$ & $\begin{array}{l}\text { - Update jumlah } \\
\text { kasus Covid-19. } \\
\text { - Mengapresiasi } \\
\text { masyarakat yang } \\
\text { terus bersama } \\
\text { mengajak orang lain } \\
\text { tetap di rumah. }\end{array}$ \\
\hline & & $\begin{array}{l}\text { "Donasi yang sudah terkumpul sebesar } 72,2 \\
\text { milyar rupiah. Banyak relawan yang bekerja } \\
\text { bersama Gugus, yaitu tenaga kesehatan daerah } \\
\text { yang bersedia membantu penyelidikan dengan } \\
\text { melakukan tracing di daerah." }\end{array}$ & $\begin{array}{l}\text { - Informasi } \\
\text { donasi dana yang } \\
\text { terkumpul. } \\
\text { - Informasi }\end{array}$ \\
\hline & & $\begin{array}{l}\text { "Terkait APD, DKI mendapat distribusi sebanyak } \\
\text { 85.000 APD, Jabar 55.000, Jateng 20.000, Jatim } \\
\text { 25.000, DIY 10.000, Bali 12.500, Banten } 10.000, \\
\text { dan daerah di luar Jawa-Bali rata-rata 5.000 pada } \\
2 \text { kali distribusi. Kita meminta rumah sakit untuk } \\
\text { menghubungi dinas kesehatan provinsi." }\end{array}$ & $\begin{array}{l}\text { - Informasi } \\
\text { distribusi APD di } \\
\text { beberapa daerah di } \\
\text { Indonesia. }\end{array}$ \\
\hline
\end{tabular}


"Terkait APD, DKI mendapat distribusi sebanyak 85.000 APD, Jabar 55.000, Jateng 20.000, Jatim 25.000, DIY 10.000, Bali 12.500, Banten 10.000, dan daerah di luar Jawa-Bali rata-rata 5.000 pada 2 kali distribusi. Kita meminta rumah sakit untuk menghubungi dinas kesehatan provinsi."

"Pentingnya memutus penularan Covid-19 bersama masyarakat, kekuatan ada di masyarakat untuk konsisten disiplin menjaga jagak dalam komunikasi sosial agar tidak ada penularan langsung dari orang positif ke orang yang rentan. Ini harus menjadi kebiasaan, hindari kegiatan yang penuh sesak, sifatnya berkumpul, dan hindari kerumunan. Banyak penularan tidak langsung melalui tangan, karena itu harus sering cuci tangan dengan sabun pada air mengalir paling tidak 20 detik."

Juru bicara pemerintah untuk penanganan Covid-19 Achmad Yurianto kembali mengungkapkan adanya penambahan kasus pasien positif Covid-19, pasien meninggal dunia, dan pasien yang sembuh.

Untuk jumlah pasien positif terinfeksi virus Corona (Covid-19) di Indonesia per Kamis (2/4/2020) mencapai 1.790 kasus. Sementara, dari jumlah tersebut, korban meninggal mencapai 170 jiwa dan angka yang sembuh 112 orang.

"Ada penambahan kasus konfirmasi positif 113, sehingga jumlah total menjadi 1.790 kasus positif akumulatif, \" kata Juru Bicara

Pemerintah untuk Penanganan Covid-19 Achmad Yurianto dalam keterangan persnya di gedung Badan Nasional Penanggulangan Bencana (BNPB), Jakarta, Kamis (2/4/2020).

Achmad Yurianto juga memaparkan bahwa dari angka itu, korban meninggal mencapai 170 jiwa.

"Ada laporan kematian dari pasien konfirmasi positif sebanyak 13 orang. Sehingga jumlah kematian menjadi 170 orang, ।" ujar dia.

Selain itu, jumlah pasien yang dinyatakan sembuh setelah menjalani dua kali tes sebanyak 112 orang.

"Ada 9 pasien yang sudah sembuh sehingga total menjadi 112 pasien, I" kata Achmad Yurianto.

\begin{tabular}{ll}
\hline 28 April & Achmad \\
2020 & Yurianto
\end{tabular}

"Sudah ada 48 laboratorium yang aktif bekerja termasuk lab di perguruan tinggi, jajaran kementrian kesehatan, laboratorium kesehatan

Pukul 12.00 WIB daerah maupun di balai veteriner dan beberapa di rumah sakit."

"Positif hari ini berjumlah 415 dengan kalkulasi 9.511 kasus, untuk kasus sembuh bertambah 103 sehingga totalnya menjadi 1254 kasus sembuh, dan kasus Covid yang meninggal bertambah 8 kasus, kalkulasi kasus meninggal hingga 28 April berjumlah 773 kasus. Untuk ODP bertambah sejumlah 3.445 kasus, sehingga Jumlah ODP sampai hari ini berjumlah 213.644 sementara PDP bertambah 441 kasus sehingga totalnya berjumlah 20.428 kasus."
- Mengingatkan pentingnya pengurangan penularan langsung dengan menjaga jarak dan penularan tidak langsung dengan rajin cuci tangan dengan sabun dan air mengalir.

\section{- Update jumlah kasus Covid-19. \\ - Himbauan untuk melakukan protokol kesehatan.}

- Peringatan untuk tidak mudik saat Hari Raya Idul Fitri (Lebaran). 


\begin{tabular}{|c|c|c|c|}
\hline & & $\begin{array}{l}\text { "Mari berpartisipasi aktif dalam penanganan } \\
\text { Covid-19 dengan memutuskan penularan } \\
\text { Covid-19, cuci tangan sesering mungkin, pakai } \\
\text { masker, hindari kerumunan, jaga jarak aman, } \\
\text { tetap produktif di rumah serta tidak melakukan } \\
\text { perjalanan ke manapun, tidak mudik." }\end{array}$ & \\
\hline $\begin{array}{l}29 \text { Mei } \\
2020 \\
\text { Pukul } \\
12.00 \text { WIB }\end{array}$ & $\begin{array}{l}\text { Achmad } \\
\text { Yurianto }\end{array}$ & $\begin{array}{l}\text { "Jumlah kumulatif kasus positif virus korona } \\
\text { (Covid-19) di Indonesia per hari ini, Jumat } 29 \text { Mei } \\
\text { mencapai } 25.216 \text { orang. Kasus ini tidak merata di } \\
34 \text { provinsi, } 5 \text { provinsi terbanyak peningkatannya, } \\
\text { DKI } 125 \text { kasus namun tidak seluruh wilayah } \\
\text { administrasi DKI karena pekerja migran Indonesia } \\
\text { yang kembali ke tanah air dan melalui Bandara } \\
\text { Internasional Soekarno-Hatta keseluruhannya kita } \\
\text { screening, lakukan pemeriksaan PCR dan banyak } \\
\text { yang positif, jadi ini bukan gambaran wilayah } \\
\text { secara keseluruhan tapi juga jadi gambaran yang } \\
\text { ada di pekerja migran kalau dilihat dari DKI saja } \\
\text { angka ini cukup stabil, kemudian yang naik adalah } \\
\text { Jawa Timur, ada 101 kasus hari ini namun jika } \\
\text { kita perhatikan dari angka kemarin, lebih menurun } \\
\text { karena kemarin } 171 \text { kasus, kemudian selanjutnya } \\
\text { kasus yang meningkat cukup tinggi di daerah } \\
\text { Nusa Tenggara Timur, dan Kalimantan Selatan, } \\
\text { dan beberapa kasus di Papua. Cukup banyak } \\
\text { provinsi yang tidak ada kasus positif, diantaranya } \\
\text { Aceh, Bangka Belitung, Jambi, Kalimantan Barat, } \\
\text { Kalimantan Utara, Sumatera Barat, Sulawesi } \\
\text { Tenggara, dan Sulawesi Barat tidak ada kasus } \\
\text { sama sekali hari ini. Dari jumlah itu, } 6.492 \text { orang } \\
\text { dinyatakan sembuh dan 1.520 orang lainnya } \\
\text { meninggal dunia." } \\
\text { "Gambaran yang kita dapatkan, bahwa kenaikan } \\
\text { 678 kasus ini tidak dimaknai bahwa ini adalah } \\
\text { kenaikan gambaran keseluruhan di Indonesia, ada } \\
\text { beberapa provinsi yang menunjukkan gambaran } \\
\text { yang datar, artinya sudah tidak ditemukan } \\
\text { kasus baru dan beberapa provinsi mengalami } \\
\text { penurunan lebih dari } 50 \% \text { dari puncak yang pernah } \\
\text { didapatkan, inilah yang secara spesifik akan kami } \\
\text { kaji terus menerus tiap provinsi dan tiap kabuaten/ } \\
\text { kota untuk kita petakan keseluruhan." } \\
\text { "Gambaran ini masih menggambarkan di beberapa } \\
\text { daerah, masih diperlukan upaya yang lebih disiplin } \\
\text { lagi agar bisa menurunkan kasus ini sehingga kita } \\
\text { bisa mengawali produktivitas yang kita tinggalkan, } \\
\text { kita juga tetap harus menjaga kebiasaan baru ini } \\
\text { atau normal baru karena ancaman Covid bersifat } \\
\text { global. Peringatan untuk tetap melakukan protokol } \\
\text { kesehatan Covid-19." }\end{array}$ & $\begin{array}{l}\text { - Update kasus } \\
\text { Covid-19 dan } \\
\text { menekanan bawa } \\
\text { gambaran kenaikan } \\
\text { tidak terjadi di } \\
\text { seluruh Indonesia } \\
\text { saja, hanya ada di } \\
\text { beberapa wilayah } \\
\text { saja. } \\
\text { - Mengingatkan } \\
\text { untuk tetap } \\
\text { melaksanakan } \\
\text { protokol kesehatan } \\
\text { Covid-19. }\end{array}$ \\
\hline
\end{tabular}




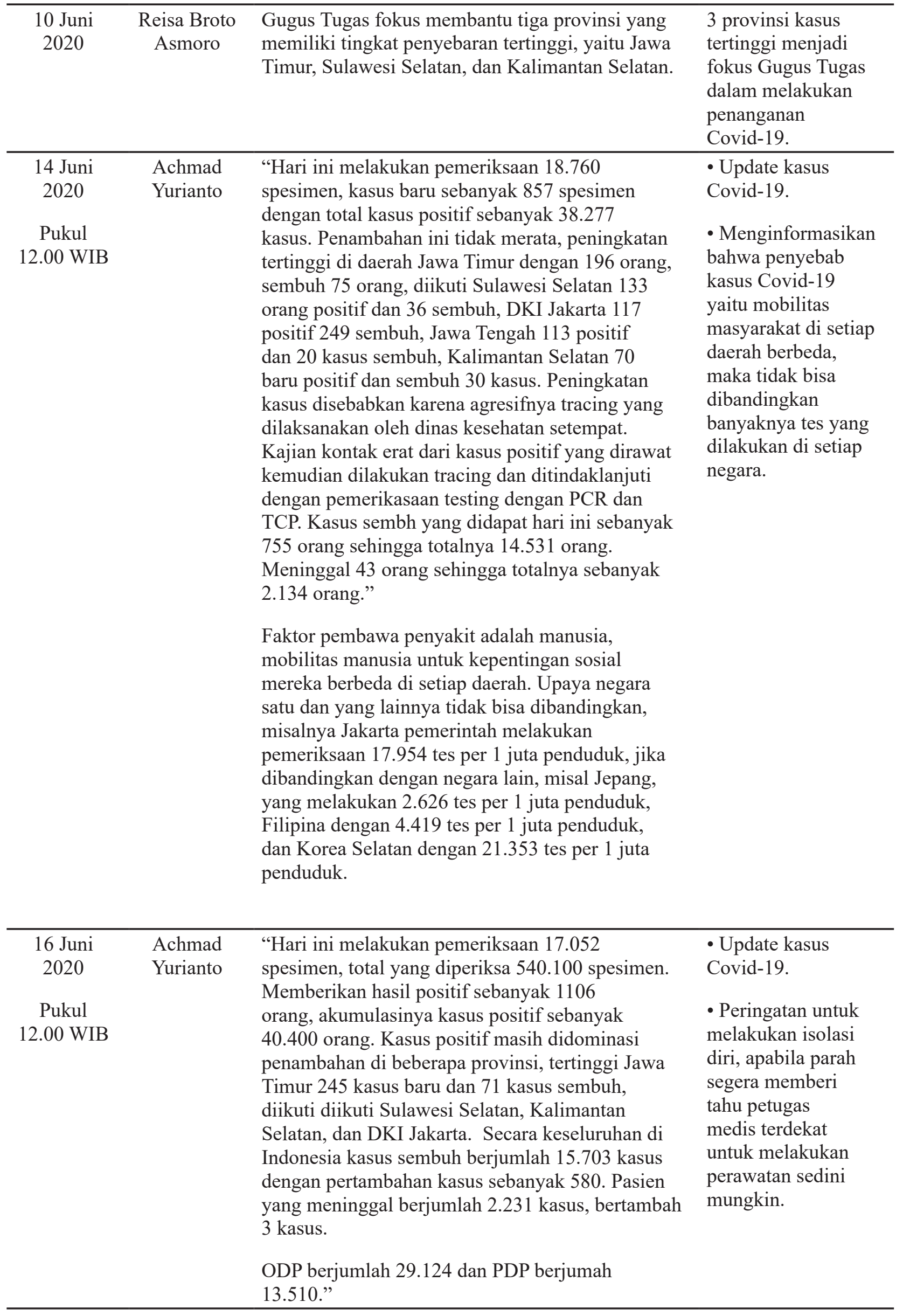




\begin{tabular}{|c|c|c|c|}
\hline & & $\begin{array}{l}\text { "Menjadi penting untuk kasus-kasus positif } \\
\text { mendapatkan edukasi untuk meaksanakan } \\
\text { isolasi dengan baik, bila terdapat gejala yang } \\
\text { menunjukkan layanan perawatan, kasus positif ini } \\
\text { langsung dibawa ke rumah sakit untuk dirawat, } \\
\text { namun jika terdapat gejala ringan diminta untuk } \\
\text { melakukan isolasi mandiri sesuai dengan protokol } \\
\text { yang sudah disampaikan." }\end{array}$ & \\
\hline $\begin{array}{l}\text { 17 Juni } \\
2020 \\
\\
\text { Pukul } \\
19.00 \text { WIB }\end{array}$ & $\begin{array}{c}\text { Reisa Broto } \\
\text { Asmoro }\end{array}$ & $\begin{array}{l}\text { Di masa pandemi, masyarakat dihimbau untuk } \\
\text { olah raga dengan intensitas ringan hingga sedang. } \\
\text { Hal ini dilakukan agar pemulihan tubuh bisa } \\
\text { lebih cepat dibanding ketika olah raga berat. Saat } \\
\text { melakukan olah raga, tubuh kita membutuhkan } \\
\text { waktu untuk kembali fit atau normal, proses ini } \\
\text { membutuhkan waktu yang lebih lama ketika } \\
\text { berolah raga berat, hal ini akan membuat kita lebih } \\
\text { berisiko terinfeksi. } \\
\text { Covid-19 adalah penyakit menular yang } \\
\text { disebabkan oleh salah satu virus korona yang } \\
\text { disebut SARSCOV2 yang pertama kali ditemukan } \\
\text { pada Bulan Desember 2019. Virus korona banyak } \\
\text { jenisnya, biasanya ditemukan pada binatang, } \\
\text { tapi ada beberapa jenis yang bisa menginfeksi } \\
\text { manusia seperti SARS di awal tahun 2000- } \\
\text { an dan MERSCOV di tahun } 2012 \text {, dan ketiga } \\
\text { SARSCOV2 saat ini menjadi pemicu status } \\
\text { gawat darurat kesehatan dunia. Virus korona yang } \\
\text { masuk ke tubuh manusia, akan menggandakan } \\
\text { diri terutama di saluran pernapasan bawah, seperti } \\
\text { paru-paru, dan mengganggu imunitas dan bagi } \\
\text { mereka yang sudah memiliki penyakit bawaan, } \\
\text { akibatnya bisa fatal. Penyebaran virus antara } \\
\text { manusia terjadi melalui droplets dari saluran } \\
\text { pernapasan. Penularan terjadi melalui kontak } \\
\text { langsung atau melalui perantara permukaan yang } \\
\text { dipegang oleh penderita. Saat berbicara, batuk } \\
\text { atau bersin, droplets dapat keluar dan menyebar } \\
\text { serta bertahan lama di berbagai permukaan objek, } \\
\text { maka dari itu penggunaan masker wajib saat } \\
\text { masa pandemi, selalu cuci tangan dengan air } \\
\text { mengalir atau cairan pembersih yang mengandung } \\
\text { alkohol, dan paling penting jaga jarak, karena } \\
\text { droplets dapat menyebar mencapai } 1 \text { meter saat } \\
\text { orang berbicara, jika batuk atau bersin virus dapat } \\
\text { menyebar hingga 3-5 meter jauhnya. }\end{array}$ & $\begin{array}{l}\text { - Olah raga ringan } \\
\text { sangat dianjurkan } \\
\text { di masa pandemi } \\
\text { saat ini daripada } \\
\text { melakukan olah } \\
\text { raga berat. } \\
\text { - Informasi klinis } \\
\text { terkait virus } \\
\text { SARSCOV2, di } \\
\text { mana virus ini dapat } \\
\text { menular dengan } \\
\text { cepat dan akan } \\
\text { berdampak lebih } \\
\text { buruk pada orang } \\
\text { yang memiliki } \\
\text { penyakit bawaan. } \\
\text { - Mengingatkan } \\
\text { untuk tetap } \\
\text { melaksanakan } \\
\text { protokol kesehatan } \\
\text { Covid-19. }\end{array}$ \\
\hline $\begin{array}{c}18 \text { Juni } \\
2020 \\
\\
\text { Pukul } \\
12.00 \text { WIB }\end{array}$ & $\begin{array}{l}\text { Achmad } \\
\text { Yurianto }\end{array}$ & $\begin{array}{l}\text { "Mengingatkan untuk jaga jarak dan cara virus } \\
\text { menyebar, serta disiplin dalam melakukan protokol } \\
\text { kesehatan. Update jumlah orang yang terpapar } \\
\text { Covid: } 42.762 \text { positif, naik } 1.331 \text { kasus; } 16.798 \\
\text { sembuh, naik } 555 \text { kasus; } 2.339 \text { meninggal, naik } \\
63 \text { kasus. Selain itu jumlah ODP sebesar } 36.698 \\
\text { kasus, PDP berjumlah } 17.923 \text { kasus. Provinsi yang } \\
\text { sudah tersebar Covid berjumlah } 34 \text { provinsi, dan } \\
\text { kabupaten/kota yang sudah terindikasi adanya } \\
\text { Covid berjumlah 435, naik } 3 \text { kota. }\end{array}$ & $\begin{array}{l}\text { - Update Covid-19. } \\
\text {-Mengingatkan } \\
\text { untuk melaksanakan } \\
\text { protokol kesehatan } \\
\text { selama pandemi. }\end{array}$ \\
\hline
\end{tabular}




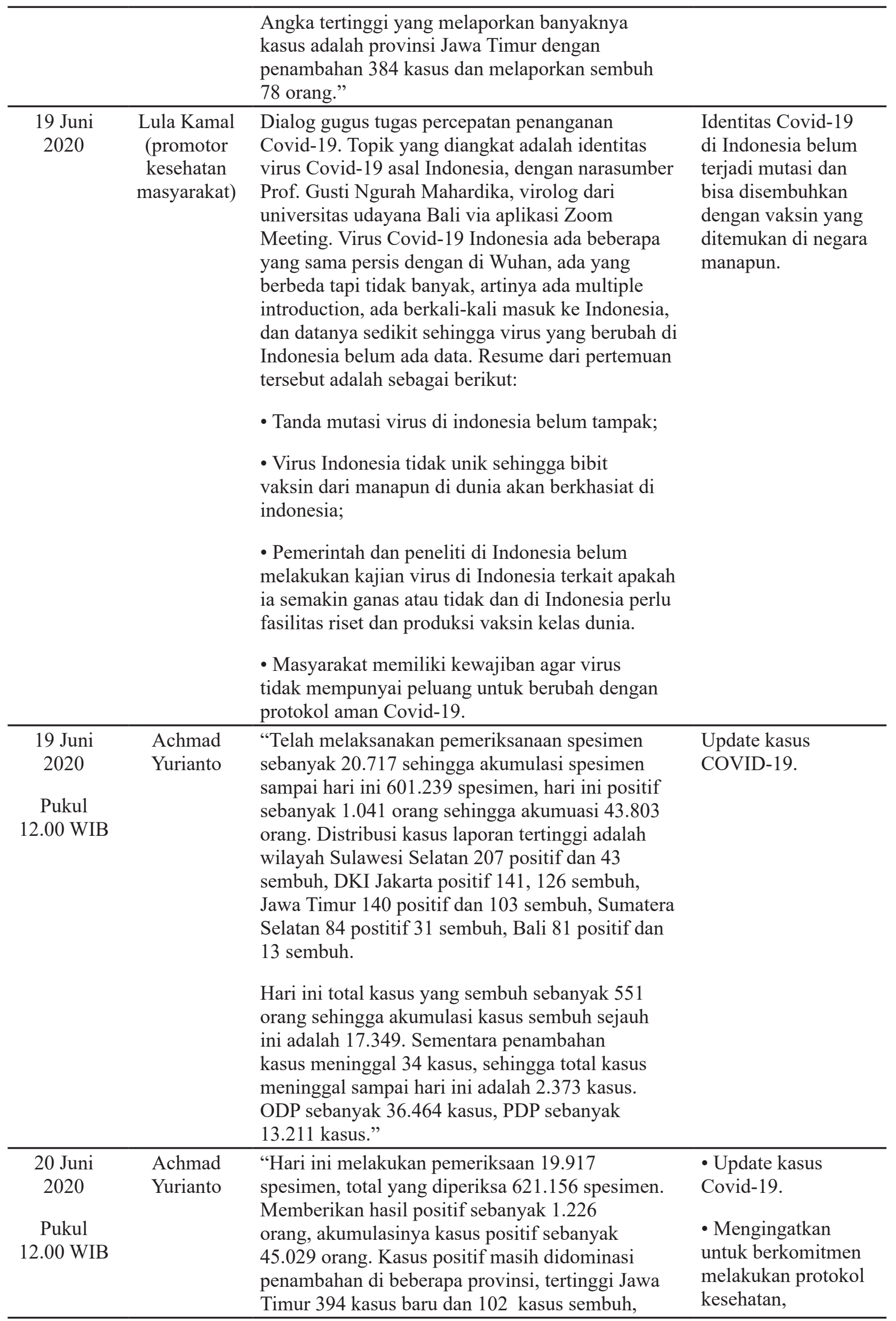


diikuti DKI Jakarta 180 orang positif dan 122 sembuh diikuti Sulawesi Selatan 112 positif dan 76 sembuh, Jawa Tengah 98 positif baru dan 20 sembuh, Kalimantan Selatan 83 kasus positif baru dan 25 sembuh. Secara keseluruhan di Indonesia kasus sembuh berjumlah 17.883 kasus dengan pertambahan kasus sebanyak 1226. Pasien yang meninggal berjumlah 2.429 kasus, bertambah 56 kasus. ODP berjumlah 37.336 dan PDP berjumah 13.150."

"Penambahan kasus ini disebabkan karena kontak tracing yang lebih agresif dan pemeriksaan yang masif, tujuannya untuk menemukan kasus positif dan melaksanakan isolasi ketat agar tidak menjadi sumber penularan di tengah masyarakat. Lalu, memperkuat komitmen untuk mematuhi protokol kesehatan, menjaga jarak hendaknya jadi kebiasaan baru, menggunakan masker maka orang yang rentan akan terlindungi dan OTG bisa melindungi orang lain karena mencegah droplets tersebar, dan kebiasaan mencuci tangan."

\begin{tabular}{cc}
\hline 21 Juni & Achmad \\
2020 & Yurianto
\end{tabular}

Pukul 12.00 WIB

\section{Positif hari ini berjumlah 862 dengan kalkulasi 45.891 kasus, untuk kasus sembuh bertambah 521 sehingga totalnya menjadi 18.404 kasus sembuh, dan kasus Covid yang meninggal bertambah 36 kasus, kalkulasi kasus meninggal hingga 28 April berjumlah 2.465 kasus. Jumlah ODP sampai hari ini berjumlah 56.436 sementara PDP totalnya berjumlah 13.225 kasus."}

"Kami melakukan pemantauan di beberapa tempat, masih kita lihat beberapa anggota masyarakat lupa menjaga jarak, padahal ini adalah hal mutlak yang harus dilakukan. Bandar udara yang akan melakukan penerbangan hari ini terutama yang menuju Jakarta, kami melakukan pemantauan di Batam dan di beberapa tempat yang lain juga demikian, banyak masyarakat yang belum tertib melakukan jaga jarak walaupun sebagian besar sudah memakai masker, karena kita tidak mungkin hanya secara parsial melakukan pengendalian penyakit, diperlukan kerja bersama terus menerus, semangat gotong royong menjadi penting untuk saling melindung, menjaga agar penularan bisa dihentikan."

\begin{tabular}{|c|c|c|c|}
\hline 25 Juni & Achmad & "Spesimen yang diperiksa sebanyak 19.510 & - Update kasus \\
\hline 2020 & Yurianto & sehingga total spesimen yang sudah diperiksa & Covid-19. \\
\hline Pukul & & didapatkan kasus positif 1.178 totalnya 50.187 & - Menginformasikan \\
\hline $12.00 \mathrm{WIB}$ & & orang, sebarannya hari ini Jawa Timur melaporkan & bahwa tempat- \\
\hline & & kasus baru positif 247 dan 241 sembuh, DKI & tempat dengan \\
\hline & & Jakarta positif 196 dan sembuh 112, Jawa Tengah & persebaran tertinggi \\
\hline & & positif 78 dan 0 sembuh, Sulawesi Selatan positif & disebabkan \\
\hline & & 103 dan sembuh 59, Maluku Utara 80 kasus baru & masyarakatnya tidak \\
\hline & & dan 1 kasus sembuh. & $\begin{array}{l}\text { disiplin melakukan } \\
\text { protokol kesehatan. }\end{array}$ \\
\hline
\end{tabular}

dan pentingnya memakai masker untuk melindungi diri sendiri dan orang lain.

- Update kasus Covid-19.

- Menginformasikan masih banyak masyarakat yang tidak melakukan pshysical distancing di tempat-tempat umum walaupun sebagian besar sudah memakai masker serta mengingatkan pentingnya kerja sama masyarakat untuk menurunkan tingkat penyebaran virus ini. 
19 provinsi melaporkan kasus di bawah 10, dan 7 provinsi yang melaporkan 0 kasus, beberapa provinsi melaporkan kasus sembuh yang lebih banyak dari kasus positif baru. Dari penyelidikan epodemologi yang dilakukan terhadap beberapa provinsi yang disebutkan di atas sebagian besar kontak erat masih dijalankan tanpa perlindungan masker, tidak menjaga jarak, inilah fakta yang menyebabkan kasus baru masih tinggi dibeberapa tempat. Tidak menjaga jarak, tidak menggunakan masker menjadi faktor utama sebaran virus ini. Hari ini 17 provinsi yang melaporkan kasus di bawah 10, dan 5 provinsi tidak ada penambahan kasus baru, jumah kasus sembuh 791 totalnya 20.449 , meninggal 47 kasus baru dan totalnya 2.620 orang."

\begin{tabular}{cc}
\hline 26 Juni & Achmad \\
2020 & Yurianto
\end{tabular}

Pukul $12.00 \mathrm{WIB}$

\begin{abstract}
"Spesimen yang diperiksa sebanyak 22.819 sehingga total spesimen yang sudah diperiksa sebanyak 731.781 spesimen. Dari jumlah ini didapatkan kasus positif 1.240 totalnya 51.427 orang, sebarannya hari ini Jawa Timur melaporkan kasus baru positif 356 dan 193 sembuh DKI Jakarta positif 205 dan sembuh 108, Jawa Tengah positif 177 dan 0 sembuh, Sulawesi Selatan positif 172 dan sembuh 156, Bali positif 49 dan sembuh 73. 19 provinsi melaporkan kasus di bawah 10 , dan 7 provinsi yang melaporkan 0 kasus, beberapa provinsi meaporkan kasus sembuh yang lebih banyak dari kasus positif baru. Total sembuh hari ini 884 dan totalnya 21.333 orang, meninggal hari inni 63 dan total 2683 orang. 448 kabupaten/kota telah terdampak Covid-19."
\end{abstract}

"Menjaga jarak menjadi kunci di samping memakai masker, beberapa ahli sudah melakukan riset di era adaptasi baru ada beberapa titik yang berpotensi bisa menjadi tempat sebaran baru yaitu ruang kantor, yang harus diperhatikan pengisian orang dengan jumlah untuk meyakinkan setiap pekerja bisa menjaga jarak 1,5 meter dengan orang lain, kemudian dipastikan bahwa kontak yang lama berpeluang terjadi penularan, maka menjaga jarak dan memakai masker menjadi hal mutlak, dan mengatur ventilasi dan sirkulasi udara menjadi penting, diupayakan penggunaan AC sebisanya tidak sepanjang waktu diupayakan setiap hari udara diganti dengan udara segar dari luar termasuk ruangan di rumah. Kemudian tempat kedua, rumah makan atau restoran. Sering kali kita dihadapkan dengan kepentingan sama di waktu yang sama, contohnya pada jam makan siang, dengan kapasitas yang dibatasi, seringkali disiplin ini tidak bisa dipenuhi, sehingga jarak satu sama lain tidak bisa 1,5 meter. Tempat ketiga, sarana transportasi massal, pemerintah sudah mengantisipasi di commuter line, dengan membagi beban penumpang pada 2 waktu yang beda,

\author{
- Menginformasikan \\ tempat-tempat baru \\ yang berpotensi \\ menjadi pusat \\ persebaran virus \\ dan himbauan yang \\ harus dilakukan \\ untuk mengurangi \\ kemungkinan \\ penyebaran yang \\ lebih tinggi.
}




\begin{abstract}
jam 07.00-07.30 dan 10.00-10.30 ini untuk memastikan kapasitas commuter diisi dengan memenuhi prasyarat jarak aman, produktivitas kita harus dilakukan kembali, mari kita kembali aktif untuk hal produktif, namun mutlak harus melakukan protokol keamanan dengan baik. Aktivitas di luar rumah semata-mata untuk produktivitas kita. Menjaga jarak, menggunakan masker, dan rajin mencuci tangan adalah jawabannya. Hal ini semua bisa diselesaikan dengan bergotong royong bersama-sama."
\end{abstract}

Sumber: Hasil Olah Data Peneliti Berdasarkan Observasi Melalui Siaran Televisi, 2020

tertuang dalam tabel (5) berikut ini, yang menyajikan tanggal, narasumber, isi berita, dan makna dari isi berita tersebut.

Berdasarkan tabel (5), informasi yang disampaikan mayoritas mengandung informasi mengenai update kasus Covid-19 setiap harinya. Informasi lain yang juga disampaikan adalah: (1) Sumber asal dari penderita kasus awal Covid-19; (2) Mengapresiasi masyarakat yang terus bersama mengajak orang lain tetap di rumah; (3) Informasi donasi dana yang terkumpul, informasi distribusi APD di beberapa daerah di Indonesia; (4) Mengingatkan pentingnya pengurangan penularan langsung dengan menjaga jarak dan penularan tidak langsung dengan rajin cuci tangan dengan sabun dan air mengalir; (5) Himbauan untuk melakukan protokol kesehatan serta peringatan untuk tidak mudik saat lebaran; (6) Menekanan bahwa gambaran kenaikan tidak terjadi di seluruh Indonesia, namun hanya ada di beberapa wilayah saja; (7) Mengingatkan untuk tetap melakuksanakan protokol kesehatan Covid-19;
(8) Tiga provinsi kasus tertinggi menjadi fokus Gugus untuk melakukan penanganan Covid-19; (9) Mengingatkan bahwa penyebab kasus Covid-19 yaitu mobilitas masyarakat di setiap daerah berbeda, maka tidak bisa dibandingkan banyaknya tes yang dilakukan di setiap negara; (10) Peringatan untuk melakukan isolasi diri, apabila parah segera memberi tahu petugas medis terdekat untuk melakukan perawatan sedini mungkin; (11) Olah raga ringan sangat dianjurkan di masa pandemi saat ini daripada melakukan olah raga berat; (12) Mengingatkan untuk melaksanakan protokol kesehatan selama pandemi; (13) Identitas virus Covid-19 di Indonesia belum terjadi mutasi dan bisa disembuhkan dengan vaksin yang ditemukan di negara manapun; (14) Mengingatkan untuk berkomitmen melakukan protokol kesehatan, dan pentingnya memakai masker untuk melindungi diri sendiri dan orang lain; (15) menginformasikan masih banyak masyarakat yang tidak melakukan pshysical distancing di tempat-tempat umum walaupun sebagian besar 
sudah memakai masker serta mengingatkan pentingnya kerja sama masyarakat untuk menurunkan tingkat penyebaran virus ini; (16) Menginformasikan bahwa tempat-tempat dengan persebaran tertinggi disebabkan karena masyarakatnya tidak disiplin melakukan protokol kesehatan; dan(17) Menginformasikan tempat-tempat baru yang berpotensi menjadi pusat persebaran virus dan imbauan yang harus dilakukan untuk mengurangi kemungkinan penyebaran yang lebih tinggi.

Jika mengacu pada tahap-tahap komunikasi risiko O’Neill, informasi dan pesan-pesan yang diberikan dalam siaran program televisi live update Gugus Tugas Covid-19 ini sudah melewati tahapan sebelum bencana (membangun ketahanan, membangun otoritas agensi darurat, meningkatkan kesadaran bahaya dan risiko, mendorong perilaku keselamatan yang sesuai, dan memberikan peringatan kepada masyarakat) dan tahapan peringatan (merancang dan menyebarkan pesan-pesan keselamatan yang kredibel); sedangkan untuk tahapan selama dan sesudah bencana hingga ke tahapan pemulihan, masih dalam proses menuju ke arah sana. Pemerintah melalui Gugus Tugas Covid-19 pun seringkali menyampaikan pesanpesan dari World Health Organization (WHO).

Sebetulnya, selain edukasi berupa komunikasi krisis yang ditujukan kepada masyarakat umum, WHO juga telah memproduksi beragam media luar ruang yang ditujukan untuk para tenaga kesehatan sebagai garda terdepan dalam "memerangi" Covid-19 ini. Tenaga kesehatan berperan penting terhadap Covid-19 dan menjadi tulang punggung pertahanan suatu negara untuk membatasi atau menanggulangi penyebaran penyakit. Di garis terdepan, tenaga kesehatan memberikan pelayanan yang dibutuhkan pasien suspek dan terkonfirmasi Covid-19, yang seringkali dijalankan dalam keadaan menantang. Petugas berisiko lebih tinggi terinfeksi Covid-19 dalam upayanya melindungi masyarakat lebih luas. Petugas dapat terpapar bahaya seperti tekanan psikologis, kelelahan, keletihan mental atau stigma. WHO menyadari tugas dan tanggung jawab besar ini serta pentingya melindungi tenaga fasilitas layanan kesehatan (World Health Organization, 2020).

Kembali pada tahapan dan bahasan mengenai komunikasi risiko, jika kita melihat "Tangga Arnstein", pemberitaan komunikasi risiko ini ada dalam bagian non-partisipasi (pengumuman darurat/mandat satu arah), manipulasi/terapi (marketing sosial/persuasi satu arah), dan informasi (kesadaran publik/ satu arah). Terkait dengan marketing sosial dan menggugah kesadaran publik dalam konteks komunikasi risiko, target yang dituju dari program semacam ini (termasuk juga siaran program live update Gugus Tugas Covid-19) 
merupakan mayoritas audiens, umumnya 60$70 \%$ total populasi. Khalayakini biasanya dalam kondisi psikologis menyangkal risiko; dan terkadang ada dalam posisi penyangkalan yang kuat (Substance Abuse and Mental Health Services Administration, 2019).

Marketing sosial bisa didefinisikan sebagai komunikasi persuasif satu arah yang menggunakan teknik-teknik marketing komersil dan peralatan untuk mendorong tujuan yang diinginkan secara sosial (O’Neill, 2004). Kampanye kesadaran publik didesain untuk menyediakan informasi mengenai bencana dan risiko-risiko terkait. Dalam tahap ini, teknik marketing yang terintegrasi digunakan untuk meningkatkan kesadaran risiko, dan mendorong serta membuat orang bisa beradaptasi dengan perilaku yang bermanfaat atau mengganti perilaku yang mungkin membahayakan mereka atau lingkungan.

Riset, pra-pengujian, evaluasi dan pendekatan yang berpusat pada khalayaksangat penting dilakukan sebelum menyelenggarakan sebuah marketing sosial. Marketing sosial berfokus pada memahami tempat pemasaran dan target audiens, bukan hanya materinya saja. Ini didasarkan pada konsep manfaat mutual-kedua belah pihak harus mendapatkan manfaat dari proses pertukaran (uang, waktu, atau ketenangan pikiran). Program yang gagal menciptakan manfaat yang tinggi dan hanya akan berdampak kecil pada target khalayak (O’Neill, 2004).

Kegiatan marketing sosial dalam konteks komunikasi risiko ini tidak akan bisa terlepas dari media massa, khususnya televisi. Seperti yang telah dipaparkan sebelumnya, Gugus Tugas Covid-19 pada awalnya hanya memiliki seorang Achmad Yurianto (Yuri) sebagai juru bicara (jubir) pemerintah dalam menginformasikan update Covid-19 di Indonesia. Namun setelahnya, Yuri dibantu oleh Reisa Broto Asmoro. Hal ini bukan saja semata penambahan sumber daya manusia di Tim Komunikasi Publik Gugus Tugas Covid-19, namun juga sebagai attention getter bagi khalayak. Dalam konteks karakteristik-karakteristik yang harus dimiliki oleh seorang komunikator agar pesan yang disampaikannya bisa efektif, selain kredibilitas, daya tarik fisik juga merupakan sebuah "kekuatan" bagi seorang komunikator, terutama seorang komunikator publik yang tampil di media massa yang bersifat audiovisual seperti televisi.

Tidak bisa dipungkiri, selain sebagai seorang dokter, Reisa juga memiliki paras yang cantik, fotogenik, dan camera-face, di samping dia juga memiliki gelar Puteri Indonesia Lingkungan 2010 dan turut berpartisipasi dalam ajang Miss International 2011. Reisa juga berpengalaman sebagai host di program $D r$. $O z$ Indonesia yang tayang di salah satu televisi 
swasta nasional Indonesia. Maka, tidak heran jika kehadiran Reisa sebagai jubir Gugus Tugas Covid-19 mendapatkan atensi yang cukup baik dari khalayak pemirsa.

Jika kita kaitkan antara jubir yang bekerja di bidang kehumasan dengan media massa, bagi humas, media massa memiliki fungsi untuk mendokumentasikan dan meningkatkan publisitas media melalui press release atau siaran pers, konferensi pers, pengorganisasi event tertentu dan kampanye kehumasan. Selain itu, media massa-termasuk di dalamnya televisi-memiliki peran besar untuk menanggulangi bencana karena media dapat meningkatkan komitmen politik untuk membuat pemimpin menjadi lebih responsif terhadap kebutuhan masyarakat rentan dan menuntut melalui pelaporan yang konsisten. Media juga dapat memengaruhi pemerintah untuk memprioritaskan isu-isu risiko bencana ke dalam komponen pembangunan melalui berbagai riset dan kajian serta laporan berkala tentang bahaya-bahaya alam (S. P. Nugroho \& Sulistyorini, 2019).

\section{SIMPULAN}

Isi berita risiko penyebaran virus SARSCOV2 dalam upaya mengurangi risiko pandemi Covid-19 pada live update Gugus Tugas Percepatan Penanganan Covid-19 di televisi nasional dalam konteks komunikasi risiko adalah yang paling banyak disampaikan (11 kali); disusul isi berita terkait informasi protokol kesehatan Covid-19 (9 kali); isi berita terkait ajakan untuk tetap di rumah dan tidak bepergian ( 2 kali); isi berita terkait informasi klinis Covid-19 (2 kali); isi berita terkait sumber Covid-19 (1 kali); isi berita terkait informasi donasi yang terkumpul (1 kali); isi berita terkait distribusi APD kepada para tenaga kesehatan (1 kali); isi berita terkait kasus-kasus Covid-19 tertinggi di 3 wilayah di Indonesia (1 kali); isi berita terkait peringatan untuk melakukan isolasi diri (1 kali); dan isi berita terkait anjuran untuk melakukan olah raga ringan (1 kali). Jika dihimpun berdasarkan komunikatornya, Achmad Yurianto adalah komunikator yang paling sering "tampil” untuk memberikan informasi (12 kai), disusul Reisa Broto Asmoro (2 kali), dan tambahan informasi dari Lula Kamal (1 kali).

Menilik dari kurang lebih 18 jenis makna isi berita yang telah dipaparkan di atas, seluruh makna isi berita dari siaran program live update televisi tersebut bersifat "menginformasikan" dan "mengingatkan", yang berarti dalam tahaptahap komunikasi risiko O’Neill, informasi dan pesan-pesan yang diberikan dalam siaran program televisi live update Gugus Tugas Percepatan Penanganan Covid-19 ini sudah melewati tahapan sebelum bencana dan tahapan peringatan, serta berada dalam bilik non- 
partisipasi, manipulasi/terapi, dan informasi dalam konsep "Tangga Arnstein”. Lebih lanjut, komunikasi risiko yang disampaikan melalui media televisi ini dapat memberikan informasi sekaligus merupakan upaya untuk menggugah sisikognisi, afeksi dan psikomotor khalayak serta menyadarkan pentingnya mematuhi protokol kesehatan Covid-19 untuk meminimalisir tingkat penularan virus SARSCOV2.

\section{DAFTAR PUSTAKA}

Abdullah, A., \& Permana, R. S. M. (2020). Pembingkaian media mengenai "Sudut Dilan" yang terinspirasi Film Dilan 1990 dan 1991. ProTVF: Jurnal Kajian Televisi dan Film, 4(1), 85-104. https://doi. org/10.24198/ptvf.v4i1.24184

Abdullah, A., \& Puspitasari, L. (2018). Media televisi di era internet. ProTVF: Jurnal Kajian Televisi dan Film, 2(1), 101-110. https://doi.org/10.24198/ptvf.v2i1.19880

Abdullah, A., Rosfiantika, E., \& Permana, R. S. M. (2017). Siaran televisi pagi hari (breakfast television) di televisi Indonesia. ProTVF: Jurnal Kajian Televisi dan Film, l(2), 163-168. https://doi.org/10.24198/ ptvf.v1i2.19875

Asteria, D. (2016). Optimalisasi komunikasi bencana di media massa sebagai pendukung manajemen bencana. Jurnal Komunikasi Ikatan Sarjana Komunikasi Indonesia, 1(1), 1-11. https://doi.org/10.25008/jkiski. v1i1.30

Bungin, B. (2011). Penelitian Kualitatif: Komunikasi, Ekonomi, Kebijakan Publik, dan Ilmu Sosial Lainnya (2nd ed.). Kencana Prenadamedia Group.
Desilvani, D., Hafiar, H., \& Damayanti, T. (2017). Citra Dirjen Bea dan Cukai pada kasus penyelundupan narkoba dalam tayangan Customs Protection NET. TV. ProTVF: Jurnal Kajian Televisi dan Film, 1(2), 105-116. https://doi.org/10.24198/ ptvf.v1i2.19870

Fahruddin, A., \& Asy’ari, N. A. S. (2019). Kajian Teori Strategi Programming Sydney W. Head pada program acara dakwah ADiTV. ProTVF: Jurnal Kajian Televisi dan Film, 3(1), 1-18. https://doi.org/10.24198/ptvf. v3i1.21207

Gemiharto, I., Abdullah, A., \& Puspitasari, L. (2017). Kajian kritis tayangan televisi favorit kelas menengah perkotaan. ProTVF: Jurnal Kajian Televisi dan Film, 1(1), 13-30. https://doi.org/10.24198/ptvf. v1i1.13329

George, A., \& Bennett, A. (2005). Case Studies and TheoryDevelopment. MITPress.https:// doi.org/10.1017/S0022381607080231

Ida, R. (2014). Metode Penelitian Studi Media dan Kajian Budaya. Kencana Prenadamedia Group.

Kurniawati， L. (2019). Implikasi standar program siaran pada tayangan edukasi dan artistik TVRI Jawa Barat. ProTVF: Jurnal Kajian Televisi dan Film, 3(2), 141-154. https://doi.org/10.24198/ptvf.v3i2.23008

Lestari, P., Astari, D. W., \& Asyrafi, A. L. (2019). Audit of disaster communication on TVOne Kabar Petang program. Jurnal Komunikasi Ikatan Sarjana Komunikasi Indonesia, 4(2), 116-127. https://doi. org/10.25008/jkiski.v4i2.332

Lestari, P., Ramadhaniyanto, B., \& Wardyaningrum, D. (2018). Pemberitaan di media online untuk pengurangan risiko bencana Gunung Sinabung. Jurnal Kajian Komunikasi, 6(1), 106-120. https://doi. 
org/10.24198/jkk.v6i1.15168

Nugroho, C. (2018). Relasi kuasa media dan isu gender dalam program televisi di Indonesia. ProTVF: Jurnal Kajian Televisi dan Film, 2(2), 111-126. https://doi.org/10.24198/ ptvf.v2i2.20816

Nugroho, S. P., \& Sulistyorini, D. (2019). Komunikasi Bencana: Membedah Relasi $B N P B$ dengan Media. Pusat Data, Informasi dan Hubungan Masyarakat, Badan Nasional Penanggulangan Bencana. Nuraini, R. (2016). Implementasi Teori Planned Behaviour dalam penggunaan siaran pers oleh jurnalis. Jurnal Komunikasi Ikatan Sarjana Komunikasi Indonesia, 1(1), 6470. https://doi.org/10.25008/jkiski.v1i1.37 O’Neill, P. (2004). Developing A Risk Communication Model to Encourage Community Safety from Natural Hazards. NSW State Emergency Service Paper.

Permana, R. S. M.,Abdullah,A., \& Mahameruaji, J. N. (2019). Budaya menonton televisi di Indonesia: Dari terrestrial hingga digital. ProTVF: Jurnal Kajian Televisi dan Film, 3(1), 53-67. https://doi.org/10.24198/ptvf. v3i1.21220

Prasanti, D., \& Fuady, I. (2017). Strategi komunikasi dalam kesiapan menghadapi bencana longsor bagi masyarakat di Bandung Barat: Studi kasus tentang strategi komunikasi dalam kesiapan menghadapi bencana longsor bagi masyarakat kawasan pertanian di kaki Gunung Burangrang, Kab. Bandung Bar. Jurnal Komunikasi, 11(2), 135-148. https://doi.org/10.21107/ ilkom.v11i2.3329

Rachmawati, L., Latifa, A., Yogaswara, H., \& Fitranita. (2014). Persepsi risiko dan komunikasi risiko bencana banjir Jakarta. Prosiding Geoteknologi LIPI, 103-111. https://jrisetgeotam.com/index.php/ proceedings/article/view/589

Rochyadi-Reetz, M., Maryani, E., \& Agustina, A. (2020). Public's media use and gratification sought during corona virus outbreak in Indonesia: A national survey. Jurnal Komunikasi Ikatan Sarjana Komunikasi Indonesia, 5(1), 111-124. https://doi.org/10.25008/jkiski.v5i1.381

Sjuchro, D. W., Khadijah, U. L. S., Hardian, M. S. D., \& Rukmana, E. N. (2019). Komunikasi kebencanaan Radio Bunut sebagai radio komunitas di Sukabumi. Jurnal Kajian Komunikasi, 7(2), 145-158. https://doi.org/10.24198/jkk.v7i2.20737

Substance Abuse and Mental Health Services Administration. (2019). Communicating in a crisis: Risk communication guidelines for public officials. Disaster Prevention and Management: An International Journal, 12(4). https://doi.org/10.1108/ dpm.2003.07312dab.004

Sulistyaningtyas, T., Jaelani, J., \& Suryani, Y. (2020). Power of knowledge and community social class above Covid-19 pandemic information on social media. Jurnal Komunikasi Ikatan Sarjana Komunikasi Indonesia, 5(1), 52-62. https:// doi.org/10.25008/jkiski.v5i1.372

Wogalter, M. S., DeJoy, D., \& Laughery, K. R. (2005). Warning and Risk Communication. Taylor \& Francis.

World Health Organization. (2020). Materi Komunikasi Risiko Covid-19 untuk Fasilitas Pelayanan Kesehatan. World Health Organization. 